disinfection protocols must be adhered to. Special attention should be given to resuscitation bags, suction, oxygen and humidification apparatus. Care of IV lines and catheters and precautions during each invasion episode like intubation, suctioning and IV injections (care bundles) is important [8,9]. Admission criteria to NICU need to be stringently defined. The number of injections, IV lines, suction and other invasions in a baby should be minimized. We must encourage early enteral feeds with human milk. A regular surveillance system is likely to open our eyes to defaults and deficiencies. Wide gaps between our knowledge and implementation exist and we have to pay attention to implementation strategies. Any break or weakness in the prevention chain can be easily taken advantage of by microbes who are natural experts in guerrilla warfare - they lie low in unfavourable circumstances, adapt and attack at any opportunity. Long term solution appears to lie in promoting healthy ways of living and augment harmony with biological nature and its forces. What it actually means in term of actions is a matter of thought and study.

Competing interest- None stated; Funding:Nil.

\section{REFERENCES}

1. Famurewa O. Microbes and Man: The endless battle. 2001. Available from: www.nuc.edu.ng/nucsite/file/ils\%202110/ ILS\%202001/ILS-44.pdf. Accessed on 29 June, 2012.
2. Sohn AH, Garrett DO, Sinkowitz-Cochran RL, Grohskopf LA, Levine GL, Stover BH, et al. Prevalence of nosocomial infections in neonatal intensive care unit patients: Results from the first national point-prevalence survey. J Pediatr. 2001;139:821-7.

3. Raju U, Dayal SS. Nosocomial infections in the NICU. In: Gupte S, editor. Recent Advances in Pediatrics, special vol 21. Delhi: Jaypee Publications; 2011.p.221-36.

4. Verma S, Jain K, Chitnis D. Rectal swabs from neonates and mothers for presence of multidrug resistant bacteria. NBE thesis 2011, Choithram Hospital \& Research Center Indore.

5. Leng R, Leal JR, Church DL, Gregson DB, Ross T, Laupland KB. The distinct category of health care associated blood stream infection. BMC Infectious Diseases. 2012;12:85.

6. Bolat F, Uslu S, Bolat G, Comert S, Can E, Bulbul A, et al. Healthcare-associated infections in a neonatal intensive care unit in Turkey. Indian Pediatr. 2012;49:951-7.

7. Adams-Chapman I, Stoll BJ. Prevention of nosocomial infections in the neonatal intensive care unit. Curr Opin Pediatr. 2002;14:157-64.

8. O'Grady NP, Alexander M, Dellinger EP, Gerberding JL, Heard SO, Maki DG, et al. Guidelines for the prevention of intravascular catheter-related infections. Pediatrics. 2002;110:e51.

9. Pronovost P, Needham D, Berenholtz S, Sinopoli D, Chu $\mathrm{H}$, Cosgrove $\mathrm{S}$, et al. An intervention to decrease catheterrelated bloodstream infections in the ICU. N Engl J Med. 2006;355:2725-32.

\title{
Secondary Cigarette Smoke Causes DNA Damage: Susceptibility for Disease Development
}

\author{
Basu Dev BanerJee ANd SMita JaIN \\ Environmental Biochemistry and Molecular Biology Laboratory, \\ Department of Biochemistry, University College of Medical Sciences, University of Delhi, \\ and Guru Teg Bahadur Hospital, Delhi, India. \\ banerjeebd@ucms.ac.in
}

$\mathrm{E}$ xposure to secondary cigarette smoke, also called environmental tobacco smoke (ETS) or second hand smoke occurs when a person (non-smoker) encounters smoke either produced from burning cigarette or exhaled from smoker. ETS is a significant health problem in children worldwide. Cigarette smoke inhalation causes cancer in various organs and smoking during pregnancy harms both mother and baby, initially retarding intrauterine development with several side-effects [1]. Various respiratory diseases such as asthma and bronchiolitis can be seen in children, even at low-level exposure to environmental cigarette smoke $[2,3]$. Cigarette smoke contains several reactive oxygen species (ROS) which may damage lipids, proteins, DNA, carbohydrates and other biomolecules. Most ROS have a short half-life and cause damage locally except $\mathrm{H}_{2} \mathrm{O}_{2}$ which has a relatively long half-life and can travel long distances causing DNA damage at distant sites. Increased production of ROS leads to an imbalance between the oxidative forces and the antioxidant defence systems, favoring an oxidative stress or injury. ROS can influence cell survival and genomic stability. 
Exposure to cigarette smoke is a significant health problem in Turkey with the prevalence of $81.6 \%$ in home and $85.9 \%$ outside the home in the children aged 13-15years [4]. Cigarette smoke contains various substances which stimulate the increased productivity of free radicals in vivo and thus disturb the oxidant: antioxidant homeostasis. Free radicals after binding to macromolecules oxidize them and lead to the production of adducts which interfere with normal cellular processes. The authors have demonstrated increased oxidative stress and DNA damage in cigarette smoke-exposed group; however, the total antioxidants level remained unaltered. Moreover, high cotinine levels in urine as observed after exposure to cigarette smoke were found to be significantly correlated with total oxidative stress (TOS), oxidative stress index (OSI) and DNA damage. DNA damage induced by ROS may contribute to increased mutation rates, genome instability, apoptosis and associated tissue regeneration and cell proliferation [5].

The intensity of smoke induced oxidative damage varies with the degree or frequency of exposure to cigarette smoke. Measuring the degree of passive smoking is of critical importance regarding the toxic effect and various health problems such as asthma and bronchiolitis, which are prevalent in children. The authors have shown significantly higher DNA damage and OSI in the group exposed to more than 10 cigarettes per day (although the statistical value was low because the number in the group was low) as compared to group exposed to $<10$ cigarettes per day. Effect of secondary cigarette smoke on TAS was not evident in either of the exposure groups. This unresponsiveness of TAS can be explained on the basis of inter-individual genetic variation which is reflected in differential antioxidant capacities in different individuals of a population [6]. This study has shown that secondary cigarette smoke is common and harmful in children and may increase the risk of carcinogenesis by inducing oxidative stress and DNA damage. The study has proved that OS and DNA damage are correlated events and together may enhance the risk of cancer in genetically predisposed individuals. The only limitation was insufficient number of control cases besides the widespread exposure to second hand cigarette smoke in the study population. Several multicentric or large cohort studies aimed at determining the relationship between DNA damage occurring in children exposed to cigarette smoke and the development of cancer are further required to validate the findings of the present study. Moreover, this study will lay foundation for identifying potential ill-effects of passive smoking with reference to health and diseases which are otherwise overlooked in present scenario.

Competing interests: None stated; Funding: Nil.

\section{REFERENCES}

1. Florescu A, Ferrence R, Tom T, Selby P, Koren G. Methods for Quantification of exposure to cigarette smoking and environmental tobacco smoke: Focus on developmental toxicology. Ther Drug Monit. 2009; 31:14-30.

2. De Sario M, Forastiere F, Viegi G, Simoni M, Chellini E, P. Piccioni $\mathrm{P}$, et al. Parental smoking and respiratory disorders in childhood. Epidemiol Prevent. 2005;29:52-6.

3. Zeyrek D, Cakmak A, Atas A, Kocyigit A, Erel O. DNA damage in children with asthma bronchiale and its association with oxidative and anti-oxidative measurements. Pediatr Allergy Immunol. 2009; 20: 370-6.

4. World Health Organization. The European Tobacco Control Report 2007 WHO Regional Office for Europe, Denmark. Available from URL: http://www.euro.who.int/ _data/assets/pdf_file/0005/68117/E89842.pdf. Accessed on 15 August, 2012.

5. Sawa T, Ohshima H. Nitrative DNA damage in inflammation and its possible role in carcinogenesis. Nitric Oxide. 2006;14:91-100.

6. Barnes PJ. Reactive oxygen species and airway inflammation. Free Radic Biol Med. 1990; 9:235-43. 